\title{
CORRIGENDUM
}

\section{International standards to document remaining autonomic function after spinal cord injury}

MS Alexander, F Biering-Sorensen, D Bodner, NL Brackett, D Cardenas, S Charlifue, G Creasey, V Dietz, J Ditunno, W Donovan, SL Elliott, I Estores, DE Graves, B Green, A Gousse, AB Jackson, M Kennelly, A-K Karlsson, A Krassioukov, K Krogh, T Linsenmeyer, R Marino, CJ Mathias, I Perkash, AW Sheel, G Schilero, B Schurch, J Sonksen, S Stiens, J Wecht, LA Wuermser and J-J Wyndaele

Spinal Cord (2009) 47, 575; doi:10.1038/sc.2008.170

Correction to: Spinal Cord advance online publication, 28

October 2008; doi:10.1038/sc.2008.121

Name of the author G Schilero was published incorrectly in the paper referenced here. The correct author list is shown above.

The authors apologize for this error. 